\title{
María Zambrano, en anhelo constante de libertad
}

«Prendamos una hoguera en tanto que amanece»

(M. Victoria Atencia)

\section{RASGOS BIOGRÁFICOS}

\section{De Vélez-Málaga, dorada y moruna}

«Hay un lugar en el Mediterráneo, Málaga, donde la tierra pierde su valor elemental, donde el agua marina desciende al menester de esclava y convierte su líquida amplitud en un espejo reverberante, que refleja lo único que allí es real: la luz. Saliendo de Málaga, siguiendo la línea ondulante de la costa, se entra en el imperio de la luz».

Estas palabras fueron escritas hace tiempo por el maestro don José Ortega y Gasset. Pues bien, precisamente en esta tierra de luz, en este paisaje de luminosidad cegadora, de vivos contrastes, entre los montes de la Axarquía y las sierras de Alhama y Tejeda, en esta ciudad blanca y roja, situada en la falda de una colina y regada por el río que le da nombre, nació María Zambrano el 22 de abril del año 1904.

Vélez-Málaga - la ciudad donde nació María Zambrano- es rica en azúcar y limoneros; también en uvas pasas, pues no en vano tiene sus «casas de viñas» y es apellidada «la capital de las pasas».

Ciudad famosa en tiempo de los Reyes Católicos, su fundación se remonta a los días de los colonizadores fenicios, habiendo sido identificada por la antigua Mainake, centro comercial de aquellos pueblos con el interior de la Península.

Conquistada al rey moro nazarita por los ejércitos de Isabel y Fernando 
en 1487, fue, más tarde, punto clave para la toma de Granada. La reina de Castilla le otorgó el honroso título de ciudad.

Se cuenta que en el sitio de la ciudad intervino el propio rey Católico, muriendo en el ataque a la Alcazaba su palafranero, Sebastián Sánchez Pelao, en cuyo recuerdo mandó construir el monarca la ermita de San Sebastián, donde reposa el cuerpo del valiente guerrero y fiel servidor del rey.

Vélez-Málaga, que celebra la fiesta de la Santa Cruz por ser el día 3 de mayo cuando entraron las tropas cristianas en la ciudad, y que tiene por patrona a Nuestra Señora de los Remedios, conserva los restos de lo que debió ser fuerte alcazaba, desde la que se contempla una maravillosa panorámica sobre el Mediterráneo, que cierra en luz la blanca y verde belleza del paisaje.

En Vélez-Málaga, para el gustador del buen arte gótico, se encuentra la iglesia de San Juan Bautista, en cuyo interior se conseryan esculturas del célebre imaginero barroco Pedro de Mena y el riquísimo «Cáliz de las Esmeraldas», decorado con no menos de trescientas sesenta y cinco piedras preciosas.

Para el que sea amigo del recogimiento y de la oración, en Vélez-Málaga está el convento de San José de la Soledad, que nos recuerda a san Juan de la Cruz, y que fue fundado por uno de sus compañeros de la reforma carmelitana.

El padre de María Zambrano, por nombre Blas José, extremeño y natural de Segura de León, era pensador y pedagogo, un hombre abierto a las nuevas ideas, liberal y amigo de Antonio Machado, con el que coincidía en muchos puntos sobre los graves problemas que aquejaban a la España de comienzos del siglo XX. La madre, Araceli Alarcón, era andaluza, de un pueblo de Almería, Bentarique, $\mathrm{y}$, como su esposo, era maestra nacional.

La España de comienzos de siglo anhelaba salir del marasmo y del aturdimiento que había producido el llamado «desastre nacional» del 1898. Dos años antes de que naciera María Zambrano, el 17 de mayo de 1902, el joven monarca Alfonso XIII, juraba ante las Cortes la Constitución de la monarquía. En el poder seguía don Mateo Práxedes de Sagasta; mas pronto la disidencia de Canalejas quebrantó al gabinete que, atacado por socialistas y conservadores, sucumbiría a finales del mismo año, dando paso a la coalición de Silvela y Maura.

Con la muerte de Sagasta, en el partido liberal se abrió el pleito de la jefatura; pleito que habría de durar mucho tiempo. En el Gobierno, el ministro Villaverde defendía un criterio restrictivo en materia financiera, que le obligó a dimitir. Silvela deseaba retirarse definitivamente de la política y aprovechó la intransigencia de Villaverde para hacerlo. Alfonso XIII confiaba en este último; pero la mayoría aclamaba por jefe al citado don Antonio Maura, que se encargó de formar nuevo ministerio. 
Don Blas José Zambrano, liberal de grandes inquietudes políticas y sociales, vivió muy de cerca los acontecimientos de aquella España que se debatía entre un pasado glorioso y un porvenir incierto e inseguro.

En Dos fragmentos autobiográficos nuestra ensayista y escritora recordará su llegada y primera estancia en Madrid, apenas cumplidos los cuatro años de su edad, yendo a vivir en la Ciudad Lineal, en la calle Redondilla, número ocho.

Poco tiempo después, la familia se trasladó a Segovia, donde el padre de María Zambrano explicará Gramática castellana en la Escuela Normal. Aquí supo «de unos caballeros templarios -escribe-, porque en Segovia, donde yo cumplí los seis años, pues, aunque nací en Vélez-Málaga, bien lejos, con mis padres fui a parar a esa ciudad impar y maravillosa donde estaban, como monumento nacional, los templarios» ${ }^{1}$.

En esta histórica ciudad estudió el bachillerato «en las aulas repletas de muchachos del Instituto Nacional», como ella misma dice. En ella, con la primera guerra mundial como experiencia triste de su adolescencia, ensayó sus primeras armas literarias en una revista de antiguos alumnos, escribiendo sobre «la suerte de Europa y la paz»; artículo que, en lugar de un premio, le va a costar una regañina de parte de don Blas José Zambrano, pues no quería en su familia «niños prodigios».

Mientras este liberal de pro hace amistad con algunos socialistas e ingresa en el partido, ella aprovechará una de estas amistades, la del poeta Antonio Machado, para sentir «su voz paternal»; si bien, para sentirla así, contribuyó no poco «el haber visto su sombra confundida con la paternal en años lejanos de adolescencia, allá en una antigua y dorada ciudad castellana» ${ }^{2}$.

Hasta dónde llegará la amistad del padre de nuestra ensayista y genial escritora con el autor de Campos de Castilla, lo dice bien a las claras la carta que Machado escribió a María Zambrano unos años después de que el escultor Emiliano Barral hiciera a un tiempo las cabezas del poeta y del progenitor de sus días: «Diga usted a su padre, mi querido don Blas, que le recuerdo mucho y siempre para desearle toda suerte de bienandanzas y de felicidades. Dígale que hace unas noches soñé que nos encontrábamos otra vez en Segovia, libre de fascistas y de reaccionarios, como en los buenos tiempos en que él y yo, con otros viejos amigos, trabajábamos por la futura República. Estábamos al pie del acueducto y su papá, señalando a los arcos de piedra, me dijo estas palabras: vea Vd., amigo Machado, cómo conviene amar las cosas grandes y bellas, porque ese acueducto es el único amigo que hoy nos queda en Segovia» ${ }^{3}$.

1. Zambrano, M., En la revista «Anthropos», n. 70-71 (1987), p. 70.

2. Zambrano, M., En «Hora de España», n. XII, diciembre de 1937.

3. Fragmento de una carta inédita, publicado por Juan Fernando Ortega Muñoz, en $M a$ ría Zambrano o la metafísica recuperada. Cf. «Anthropos», 1.c., p. 74. 
María Zambrano, cumplidos los veintidós años, se traslada a Madrid con su familia. Días históricos, también aquéllos, con el hombre fuerte que es don Miguel Primo de Rivera. En la capital de España completa sus estudios de Filosofía y Letras en la Universidad Central, donde asiste a las clases de José Ortega y Gasset, a las de Manuel García Morente y a las de Javier Zubiri. La Universidad, el aire de Madrid y la claridad de este pueblo «salvarán su razón» y le harán comprender la importancia de tener amigos y compañeros.

Estos amigos y compañeros le llevarán luego a ingresar, para bien o para mal de su vida, en la Federación Universitaria Española (FUE); lo que abrirá ante ella - pues ha de ser un miembro activo de la misma - «una dimensión salvadora de la política».

María Zambrano y aquel grupo de jóvenes estudiantes de avanzadilla querían ser «serios del modo más alegre»; y así lo manifiesta ella en las primeras colaboraciones periodísticas que le proporciona El liberal.

El año 1928 marcará un hito importante en su vida política: Es el año en que se crea la Liga de Educación Social, tras haber presentado y leído este grupo de amigos un escrito a intelectuales maduros, de la talla de don Gregorio Marañón, Indalecio Prieto, Ramón Pérez de Ayala y don Ramón del Valle Inclán, entre otros.

Año histórico y decisivo - éste de 1928 - en la existencia de nuestra gran ensayista, por cuanto en un acto público, celebrado en Valladolid junto al que habría de ser pronto su cuñado, el prestigioso médico Carlos Díez Fernández, éste le dará a escoger, en un diagnóstico cruel, entre tres años de sanatorio, o tres meses de vida.

Afortunadamente, para gloria de las letras españolas, se recuperó de su enfermedad y su internado le libró, además, de asistir a la triste disolución de la mencionada Liga de Educación Social, cuando, a finales del 1929, la policía asaltó su local.

Años de juventud inquieta; juventud de una intelectual, de una universitaria que meditaba y reflexionaba, no sólo sobre el grave problema de España -la dictadura de don Miguel Primo de Rivera se ha desmoronado, dando paso al interregno del general Berenguer-, sino también en problemas de historia, de poesía, de filosofía... En su mente surge una de sus grandes teorías que plasmará más tarde en su libro Hacia un saber sobre el alma ${ }^{4}$, y en el que aparece ya su concepción de la razón poética como «razón de amor reintegradora de la rica sustancia del mundo», y donde dejará escrito que «pueblo y poeta son íntimamente hermanos». Una idea ésta que le hará decir en una car-

4. Zambrano, M., Hacia un saber sobre el alma. Ed. Losada, Buenos Aires 1950. 
ta dirigida a don Gregorio Marañón: «Buscaremos la libertad y la razón con más esfuerzos que nunca, y las buscaremos allí donde el poder de creación se alberga en las entrañas de la historia que no pueden estar más que en el pueblo».

Profesora auxiliar de la cátedra de Historia de la filosofía en la Universidad de Madrid, por ausencia de Zubiri, en este momento ha publicado ya su primer libro, titulado Nuevo liberalismo, el cual llevará en cubierta este otro de Horizonte del liberalismo.

María Zambrano se encuentra en un momento en el que querría robarle al día y a la noche más horas, para poder leer y escribir. Lee a Spinoza y prepara un estudio sobre este gran filósofo neerlandés, descendiente de judíos españoles, emigrados tiempo atrás a los Países Bajos, y su doctrina panteísta, que ha dejado huella profunda en numerosos pensadores y ha fecundado las filosofías de Fichte, Schelling y Hegel.

El día 14 de abril de 1931, María Zambrano, cogida del brazo de J.A. Maravall, avanzó hacia la Puerta del Sol, donde fue proclamada la República. Cuando pasen los años, residiendo en Chile, escribirá en su libro Los intelectuales en el drama de España ${ }^{5}$ lo siguiente: «En abril de 1931 el pueblo había mostrado su cara, la cara de la alegría y de la gloria que no conocíamos los españoles. Nunca habíamos estado juntos tan contentos, porque nunca habíamos estado contentos, y muy pocas veces juntos».

Uno se pregunta, después de leer estas palabras, si María Zambrano no tuvo que decir, más tarde, con su maestro Ortega, aquello de «no era esto; no era esto»...

Los años de la República los pasa en una actividad intelectual endiablada: colabora en la revista «Los cuatro vientos»; y en la «Revista de Occidente», en la que publica lo que podemos llamar su primer ensayo, que lleva el atractivo título de Por qué se escribe; al que va a seguir Hacia un saber sobre el alma; da conferencias en distintos ateneos; trabaja en su tesis doctoral sobre el tema «La salvación del individuo en Spinoza»; en compañía del citado J.A. Maravall y de Luis Cernuda recorre diversos pueblos y remotas aldeas «llevando hasta sus gentes una imagen de la cultura, de la que por tradición les pertenecía, y de la desconocida (el cine, la pintura, el teatro o la música clásica...» ${ }^{6}$.

5. Zambrano, M., Los intelectuales en el drama de España. Ed. Panorama, Santiago de Chile 1937.- 2. ${ }^{\text {a }}$ edición, aumentada, 1939.- Nueva edición, Ed. Hispamerca, Madrid 1977.

6. Castillo, Julia, Cronología de María Zambrano. En «Anthropos», 1.c., p. 76. 
Luego llegó la guerra, que le sorprendió en aquel Madrid viejo, donde vivía - según recuerda Camilo José Cela - en una casa acogedora y llena de libros, en la que recibía a los amigos los domingos por la tarde, invitándoles a una taza de té. María Zambrano recordará en algunos de sus escritos los primeros momentos del estallido en aquel Madrid «luminoso y espléndido en su tragedia, en el Madrid inolvidable, todavía intacto, de julio y agosto de 1936».

Es en este mismo año y a los pocos días de enfrentarse las dos Españas en duelo fratricida, cuando nuestra escritora contrae matrimonio con Alfonso Rodríguez Aldave, historiador y diplomático, afín a ella en sus ideas republicanas.

Nombrado éste secretario de embajada en Chile, realizan los dos un viaje inolvidable, visitando la ciudad de Lisboa, las islas Azores, la Habana, Panamá, Ecuador, Perú y, finalmente, la meta del destino: Santiago de Chile.

\section{En el exilio, añorando a España}

En esta última ciudad chilena, lejos de la patria, que se debate en una guerra que María Zambrano no acaba de entender y que su causa republicana tiene perdida, publica la citada obra Los intelectuales en el drama de España. Pero estaba escrito que este drama habría de vivirlo más de cerca y aun sufrirlo vivo en su propia carne. Por el mes de junio de 1937, nuestra escritora y su marido, que ha sido llamado a filas, regresan a España, residiendo luego en Valencia y Barcelona.

Mientras Alfonso se incorpora en el ejército de la República, su esposa colabora activamente en defensa de la misma en calidad de consejero nacional de la Infancia evacuada; «lo que supone una dolorosa entrega en sus visitas a las guarderías infantiles».

Colabora, igualmente, con su pluma en la revista valenciana «Hora de España», donde tiene la ocasión de conocer y hacer una gran amistad con el poeta malagueño Emilio Prados ? . Refiriéndose a estos días febriles y a este poeta malagueño, : Zambrano escribirá unos años más tarde: «Nos veíamos continuamente, y en este verse de continuo se hablaba de la Revista cuando

7. Emilio Prados había nacido en Málaga el año 1899. Murió en México en 1962. En su ciudad natal montó la imprenta Sur, editora de la revista «Litoral», que dirigió él mismo con Manuel Altolaguirre. Sus primeros libros, Tiempo y Canciones del farero, le sitúan entre los poetas de la llamada generación del 27. Intentó la poesía política, a la vez que buscaba nuevos medios de expresión en el follage y otras artes plásticas. La guerra civil española le inspiró Llanto de sangre, publicado en 1937. Colaboró -lo mismo que María Zambrano- en la revista «Hora de España». Terminada la contienda, se exilió, residiendo en México, donde siguió escribiendo libros de poesía, que han quedado en gran parte inéditos. El año 1954 se publicó una Antología, que reúne poemas que van desde el año 1923 a este ứltimo citado. 
era necesario. Rafael Alberti con su presencia en Madrid nos asistía. Emilio Prados era el que pasaba por el local de la redacción y con su oficio del arte poética de imprimir la cuidaba»...

Durante su estancia en Barcelona, casi al final de la guerra y en vísperas de ser tomada la Ciudad Condal por las tropas victoriosas de Franco, María Zambrano tuvo tiempo y humor para dictar un curso de filosofía.

Antes de que termine el año 1938, la muerte arrebatará la vida de su padre, del que Machado escribirá en su Mairena póstumo: «Era don Blas Zambrano, cuando le conocí en Segovia, hombre maduro, frisando en los cincuenta, figura varonil aunque nada imponente, la cabeza, entre romano y florentina, muy noble. Algunos pensábamos al verle en el Niccolo Uzzano, de Donatello. Emiliano Barral lo esculpió en piedra durísima y le llamaba - a don Blas y a su busto de piedra- el Arquitecto del Acueducto. Y así acabamos llamándole todos, con expresión familiar, no exenta de ironía por lo desmesurado del anacronismo, pero que no excluía el respeto, ni mucho menos, la estimación... Vi a don Blas por última vez en Barcelona, acompañado de su hija -esta María Zambrano que tanto y tan justamente admiramos todos-. Pláceme recordarlo así, ¡tan acompañado!» ${ }^{8}$.

A comienzos de 1939 la guerra tocaba ya a su fin. El día 28 de enero María Zambrano cruzaba la frontera francesa, camino del exilio. Le acompañaba su madre, su hermana Araceli y el marido de ésta. Tras una estancia breve en París y más breve todavía en Nueva York, se establecen en la Habana, donde se encuentran de nuevo con el viejo amigo Lezama Lima ${ }^{9} \mathrm{y}$ donde vuelve a tener la oportunidad de dar a conocer, por medio de una conferencia, al maestro Ortega y Gasset.

Más tarde nuestra escritora es reclamada por la Universidad de San Nicolás de Hidalgo, de Morelia, en Michoacán, para explicar la cátedra de filosofía. Alfonso Reyes y el poeta de Tábara, León Felipe, se disputan la amistad de nuestra ensayista y escritora. Aquí, en México, podrá ultimar y dar a la estampa dos de sus obras fundamentales: Pensamiento y poesía en la vida

8. Cf. «Anthropos», Julia Castillo, n. 70-71, p. 77.

9. José Lezama Lima, poeta cubano, nació en la Habana el 1910, y murió en la misma capital en 1976. Licenciado en Derecho, desde joven participó en las manifestaciones estudiantiles contra el régimen machadista. Trabajó en el Consejo superior de defensa social de 1941 a 1949, y posteriormente pasó a la dirección de Cultura del ministerio de Educación. Más tarde fue asesor en el instituto de literatura y linguística de la academia de ciencias. Desde el año 1962 fue vicesecretario de la unión de escritores y artistas de Cuba. Fundó cuatro revistas: «Verbum», «Escuela de plata». «Nadie parecía», y «Orígenes», esta última en colaboración con José Rodríguez Feo, donde publicó algunos cuentos imaginativos y varios capítulos de su novela titulada Paradiso, publicada íntegra en 1966. 
española ${ }^{10}$, y Filosofía y poesía ${ }^{11}$. Colabora en la revista «Sur», de Buenos Aires, con un magnífico ensayo sobre San Juan de la Cruz, de la noche oscura a la más clara mística.

Nuevamente en Cuba, invitada esta vez por la Universidad de la Habana, se incorpora al grupo de jóvenes escritores que redactaban la revista «Espuela de Plata». Es en este preciso momento -año 1940-, cuando encuentra en la «Perla de las Antillas» a quien va a ser - como ella misma dice-su guía en el exilio: el doctor Gustavo Pittaluga.

A su paso por Puerto Rico, en 1943, encuentra a Pedro Salinas. De esta época es El pensamiento vivo de Séneca ${ }^{12}$. Poco antes de que muriera su madre en París, le dedica a ésta La agonía de Europa ${ }^{13}$. Precisamente será en $\mathrm{Pa}$ rís donde ha de fijar su residencia hasta el 1949 en que, separada de su marido y en compañía de su hermana Araceli, marcha a Nueva York, dejando atrás el recuerdo nostálgico de Octavio Paz y el de Jorge Guillén, poeta eximio de la generación del 27, y autor de Cántico, uno de los libros de poesía más memorables que se hayan escrito en lengua española.

Larga estancia ahora de nuestra pensadora en la Habana - hasta el 1953-, dictando lecciones sobre la filosofía de Ortega, y publicando libros tan interesantes como Hacia un saber sobre el alma, citado y anotado arriba.

En este mismo año la encontramos ya en Roma, siempre al lado de su hermana Araceli, donde residirá toda una década, consagrada a la pluma, colaborando en distintas revistas, dictando lecciones de filosofía y publicando nuevas obras, como El hombre y lo divino ${ }^{14}$.

El libro Claros del bosque lo concibe en el tiempo en que vive en una vieja casona de campo en la Pièce, junto a un bosque del Jura francés ${ }^{15}$. Todavía antes de que regrese a España, habrá de morar por algún tiempo en Suiza, en una gran serenidad de alma y mientras en su patria -en la prensa y radio- se habla con fervor de ella.

\section{De regreso a la patria}

El año 1981, María Zambrano, ausente de España desde la guerra civil, le dedica un recuerdo encendido en la entrevista que concede al periodista José

10. Zambrano, M., Pensamiento y poesía en la vida española. Ed. La Casa de España, México 1939. co 1939.

11. Zambrano, M., Filosofía y poesía. Publicaciones de la Universidad Michoacana, Méxi-

12. Zambrano, M., El pensamiento vivo de Séneca. Ed. Losada, Buenos Aires 1944.

13. Zambrano, M., La agonía de Europa. Ed. Sudamericana, Buenos Aires 1945.

14. Zambrano, M., El hombre y lo divino. F.C.E., México 1955.

15. Zambrano, M., Claros del bosque. Ed. Seix Barral, Barcelona 1977. 
Miguel Ullán por radio nacional. Este mismo año es galardonado con el premio «Príncipe de Asturias de comunicación y humanidades» por la Fundación Principado de Asturias. Un año después, la Junta de Gobierno de la Universidad de Málaga acuerda el nombramiento de María Zambrano como doctora honoris causa de la misma.

Segovia le rinde un homenaje pocos días antes de que llegue a España en noviembre de 1984. María Zambrano, con muchos años encima, pero muy contenta, y hasta feliz, se instala en Madrid. Hoy está presente en el campo de la literatura y de las buenas letras. Hasta el punto de que J.A. Ugalde ha llegado a decir, en memorable artículo titulado «Mística de la vida y nacimiento en el amor», que pocos escritores de este siglo han captado con la personal intensidad de María Zambrano la esperanza medular que recorre la modernidad: el anhelo que en el hombre trasciende a la razón. Pocas obras han alcanzado la capacidad de sugestión de sus escritos para transmitir y actualizar la filosofía y la actitud vitalistas de finales del siglo XIX: reclamación de un saber que sea cauce de vida, de la vida entera; que aúne en órbitas concéntricas el fluir de la conciencia y el latir del corazón, para que un dardo de luz traspase, al fin, la diana» ${ }^{16}$.

Para Camilo José Cela, María Zambrano «es una de las mejores cabezas de todos los tiempos». Y Cioran ha dicho que nuestra escritora pertenece «a ese orden de seres que lamentamos no encontrar más que en raras ocasiones, pero en los que no cesamos de pensar y a los que quisiéramos comprender o, cuando menos, adivinar. Un fuego interior que se esconde, un ardor que se disimula bajo una resignación irónica: todo en María Zambrano desemboca en otra cosa, todo conlleva a otro lugar, todo. Por mucho que uno pueda hablar con ella de cualquier cosa, se tiene, sin embargo, la certeza de que antes o después nos deslizaremos hacia interrogantes esenciales sin seguir necesariamente los meandros del razonamiento. De ahí un estilo de conversación en nada entorpecido por la tarea de la objetividad y gracias al cual ella nos conduce hacia nosotros mismos, hacia nuestras preocupaciones mal definidas, hacia nuestras perplejidades virtuales...» ${ }^{17}$.

Nombrada hija predilecta de Andalucía en 1985, la Universidad de Sevilla edita el número primero de la revista «Claros del bosque», en tanto que en su patria chica se le rinde un cariñoso homenaje. Dos años más tarde, la acreditada revista «Anthropos» saca un número dedicado a hacer una antología de textos de nuestra eximia escritora; mientras queda en propósito la creación de la Fundación que lleve su mismo nombre.

16. Cf. «Anthropos», Editorial, 1.c., p. 15.

17. CIORAN, E.M., El ensombrecedor magisterio de Ortega. En «Anthropos», n. 70-71 (1987), p. 2. 
Y ella, María Zambrano, espera en plenitud de años y de lucidez mental, en madurez de vida y de obra, la hora del marchar...

\section{ENSAYISTA Y PENSADORA}

Al tiempo de hablar de sus propios escritos, María Zambrano dice lo siguiente: «Mi pensamiento se entrega, se da; yo me doy por completo, sin esperar... He aceptado siempre la verdad, me lleve donde me lleve, me traiga lo que me traiga».

En la citada revista «Anthropos» y más concretamente en su casi exhaustiva Editorial, se estudia a nuestra ensayista y pensadora como «Presencia y figura de la aurora; Iniciación de transparencia y verdad; como sentir poético de lo originario; como espera amorosa de una revelación»».

El mismo editorialista se pregunta por donde empezar... Efectivamente, después de una atenta lectura de uno cualquiera de sus libros - glosaremos más adelante Filosofía y poesía y Delirio y destino-, uno queda como empapado, ebrio de cultura; pero también un tanto aturdido y como confuso; pues es tanto lo que se nos quiere decir, que bien podemos aplicar aquello de que «los árboles impiden ver el bosque».

«Poetas de la luz y del fuego - leemos-; encuentro en la intimidad con la presencia hallada en la orilla, en el extremo de todo; lugar de revelación y transparencia; visión de lo invisible. Poetas, místicos y narradores son su compañía, amigos de indagar, de sondear el universo y la historia en busca de aquel a quien más quieren, los ojos dibujados de una figura en el agua, en el aire y en el fuego. Poetas de pensamientos y de cuentos, relatos, pasos, mitos y misterios; secretos en la escritura escondida en el tiempo y en la ruina, en las entrañas, en la razón, en la vida; caravana de amigos en vuelo sobre el camino, compañeros de indagación, pueblo e intelectuales, hombres mediadores de una revelación y presencia. En esa barca navega el pensar y el sentir de María Zambrano: busca y espera la revelación, sondea los secretos escondidos en las aguas profundas y en los abismos infernales de la historia. Apura el vaso hasta el final y ahí está el hombre verdadero. La luz que enciende toda verdad y estancia» ${ }^{18}$.

Ella y su escritura, sigue diciendo el editorialista, son un misterio, un secreto guardado en la oscuridad del corazón, de las entrañas, en el fondo; pero siempre es guía y mediación, maestra de un saber en el límite, en conexión con todo lo viviente, en su raíz, en su origen y génesis...

18. Editorial de la revista «Anthropos», l.c., p. 2. 
Como hemos de ver más adelante, María Zambrano nos habla de sí misma en sus escritos y en su vida de una forma indirecta, como sin querer. Su escritura se convierte en documento, en obra o fragmento de vida donde podemos rastrear su revelación y transparencia, su palabra y su pensamiento. En este sentido, lo que más le ha costado es asumir «el yo» de su obra; pero sabe que ese yo, que no es nadie, guarda la responsabilidad moral a la que no puede sucumbir, ni tampoco «a una especie de sentir radical» que de hecho ha nacido dentro de ella.

Oigámosla en un párrafo hermoso: «Cuando el alguien aprisionado y ávido que va en nosotros sale a la luz, no encuentra aquello que lo hizo salir. Al salir de sí, nadie parecía, aquello amado se ha ido y sólo encontramos el vacío, la negación. El «no», cualquier no, sabemos lo que significa sólo cuando se ha pasado por la experiencia de lo negativo.

Sabemos que ello, lo esperado, no está ahí, ni cerca ni lejos. $Y$ entonces nos damos cuenta de que vivimos solos. $Y$ vivir a solas es vivir a medias, es estar recluido, cegado también; es estar en reserva y a la defensiva.

Se puede morir estando vivo. Se muere de muchas maneras, en ciertos padeceres sin nombre, en la muerte del prójimo, y más todavía en la muerte de lo que se ama y en la soledad que produce la total ausencia de posibilidad de comunicarse, cuando a nadie le podemos contar nuestra historia. Eso es muerte, y muerte por juicio. El juicio de quien debía oír y entrar sin más en el interior de nuestra vida es la muerte. "Vivir es convivir», ha dicho Ortega, y cuando la convivencia se hace imposiblế porque el que convive interpone y arroja su juicio sobre la persona viva, sobre aquello que nace solamente cuando se comparte, se hace la muerte ${ }^{19}$.

Cuando escribe y en cuanto escribe, ella sabe lo que dice. De lo que uno duda es de que siempre le entienda el lector medio, ya que, al igual que su maestro Ortega y Gasset, juega mucho con la metáfora y con el lenguaje figurado; lo que no está al alcance, por desgracia, de muchos lectores, a la hora de encontrar el significado que tiene en la realidad de las cosas.

Con todo, habrá que reconocer que su escritura es un don, una comunicación de sabidurías antiguas, vencidas, pero nunca aniquiladas. Nos ofrece siempre, en sus obras, un documento rico y profundo, resumen de muchas sabidurías, métodos, caminos y presencias; lo que constituye una llamada, una vocación humana, «un desnacer naciendo».

En otro lugar de sus escritos autobiográficos enuncia maravillosamente -y a mí en este pasaje me recuerda mucho a Azorín - el paso de las horas, el

19. Zambrano, M., El nacimiento (dos escritos autobiográficos). Entrega de la Ventura, Madrid 1981 
paso «de las vestiduras del tiempo, en el que surge el instante - «unidad de los tiempos múltiples, transparencia en el tiempo confuso»-, y en el que se nos da -solamente en él - la imagen de la felicidad ligera, leve. «Y ahora iba sintiendo que en ese vivir el instante - leemos en La multiplicidad de los tiempos-, que absorbía a tantos de los mejores y que era la consigna del momento, había ese anhelo de librarse de la sucesión, de despojarse del pasado y quedarse inocente; la búsqueda exasperada de la inocencia en "esta cultura», después de tres siglos de exasperación de vivir según la «conciencia». ¡Y salir de sí, vivir fuera de sí, corriendo al encuentro de algo que colme por completo el vacío, que haga cesar el anhelo y ese tormento de la esperanza que no encuentra su argumento o que se lo sitúa tan lejano!. "Aquí y ahora» parecía ser la consigna común de los jóvenes, con la cual se entendían por encima de cualquier diferencia, sobre las fronteras. A la conquista del tiempo perdido, del instante. Como la «piedra filosofal» de los alquimistas, la «flor azul» de los románticos alemanes, forma «laica», y por tanto más modesta...» ${ }^{20}$.

Lo importante para María Zambrano, en este punto es «marchar con», convivirse y esperar el conocimiento que solamente se da al final, consumiendo entretanto la vida en el fuego de los tiempos.

Como ensayista y pensadora, María Zambrano pertenece al grupo de los escritores españoles que, con mayor o menor éxito, han cultivado este género, juntamente con la crítica literaria y la erudición filosófica. Ella encaja perfectamente en ese grupo de filósofos y humanistas de la posguerra, discípulos todos ellos e influenciados por don José Ortega y Gasset y por Javier Zubiri, a los cuales tuvo la suerte de escuchar en la Central de Madrid.

Entre estos hombres se encontraba don Pedro Laín Entralgo, uno de los escritores que con más ahínco han defendido, desde una postura católica, la necesidad de comunicación con el mundo cultural europeo. «Partidario del diálogo y de la convivencia, toda su obra se halla presidida por un noble deseo de comprensión serena. Catedrático de historia de la medicina, ha dedicado libros a su especialidad, y al mismo tiempo, a temas en relación con la historia cultural de España..., donde queda de relieve su hondo conocimiento del pensamiento religioso cristiano» ${ }^{21}$.

Otro ejemplo, en la misma línea de Laín Entralgo y afín en cuanto se refiere a la aproximación a la cultura europea, lo encontramos en José Luis Aranguren, conocedor de la teología cristiana, catedrático de ética en la Uni-

20. ZAMBRANo, M., La multiplicidad de los tiempos (dos escritos autobiográficos). Entrega de la Ventura, Madrid 1981.

21. García López, J., Historia de la literatura española. Ed. Vicens Vives, Barcelona 1966, p. 694. 
versidad de Madrid, autor de ensayos y estudios, en los que se manifiesta el deseo de asumir, desde un punto de vista católico, y con criterios abiertos, las inquietudes del mundo actual en el campo religioso, estético, moral y político.

Discípulo de Ortega, al igual que nuestra María Zambrano, con amplia apertura hacia Europa, con sentido católico de la vida y con un profundo amor a España, es Julián Marías, autor de numerosos artículos y ensayos sobre temas diversos; de libros filosóficos, donde se echa de ver el claro influjo del maestro, a quien ha dedicado varias obras de fervorosa exégesis y comentario.

Al margen de la línea católica, pero preocupado también por las circunstancias del hombre actual, nos encontramos con José Ferrater Mora, autor de un gran Diccionario de la Filosofía, y de un libro muy interesante, titulado La filosofía en el mundo de hoy.

Precisamente será este autor el que, comentando los escritos de María Zambrano sobre filosofía y poesía, se refirirá al tema central «la vida filosófica y la vida poética», en que destaca cómo se oponen y cómo se complementan. una y otra disciplina.

Nuestra ensayista y pensadora, profesora en la Universidad Central antes de la guerra civil española y después dictando lecciones y escribiendo libros en el exilio, está considerada hoy como una de las figuras más representativas en el campo de la cultura nacional, de modo especial, en los campos de la crítica, de la erudición y de la filosofía.

En plena guerra civil publicó el citado libro Los intelectuales en el drama de España; y ya en el exilio El pensamiento vivo de Séneca, también reseñado en páginas anteriores. Seguirán luego Hacia un saber sobre el alma; El hombre y lo divino; España, sueño y verdad, libro éste de madurez intelectual y de serenidad, al igual que El sueño creador que ve la luz pública en $1965^{22}$.

No acaban aquí las obras de ensayo de la ilustre malagueña. Filosofía y poesía, reeditada recientemente y que más adelante hemos de comentar por extenso, es obra fundamental y libro clave en la trayectoria filosófico-literaria de María Zambrano. A este libro hay que añadir El freudismo, testimonio del hombre actual ${ }^{23}$, y el más reciente Clarós del bosque, publicado en 1977 y reseñado arriba.

Un regalo para las letras españolas y un libro que es mitad novela y mitad memorias autobiográficas es Delirio $y$ destino, presentado impecablemente

22. Zambrano, M., El sueño creador. Ed. Universidad Veracruzana, Xalapa (México), 1965.

23. ZamBrano, M., El freudismo, testimonio del hombre actual. Ed. La Verónica, La Habana 1940. 
por «Mondadori» y aparecido en 1988. Un libro éste que, según confesión de la propia autora, fue escrito hace cuarenta años y quiere ser, hasta el momento, la única novela - si se le puede llamar así- que conocemos suya; pero que tiene mucho de ensayo filosófico y de biografía personal e íntima de los años en que estudiaba en la Universidad, admiraba a Unamuno, se unía al grupo de jóvenes que anhelaban renovar el verdadero pulso y pensamiento nacional, y que le tocó vivir los años difíciles inmediatamente anteriores a la guerra civil.

\section{GLOSA Y COMENTARIO AL LIBRO «FILOSOFÍA Y POESÍA»}

María Victoria Reyzábal, en un breve comentario recensivo del libro Filosofía y poesía, dice que no le importa dilucidar si el pensamiento de María Zambrano resulta certero o equivocado. Ni tampoco con qué corrientes parece emparentado, simpatías que la inundan o rechazos que pueden configurarla. Lo que le interesa es resaltar su ansia poética, su amatoria literaria, titánica y justiciadora de raíces, caminos y vuelos. «Más que muchos poetas consagrados, atentos a cada adjetivo, decidores de bellezas o atrocidades, ella hace su poesía desde el pensar y más aún desde el ser. Mujer de la introspección lírica, su prosa manifiesta la lucha contra la palabra para la gran palabra, la búsqueda del verbo justo, primigenio, mítico-místico capaz de dar cuenta de lo sagrado, de la razón y la sinrazón» ${ }^{24}$.

María Zambrano se muestra en Filosofía y poesía como una pensadora que siente; como una artista que delibera; como una española tanto de fuera como de dentro, con una fuerza vital que rompe moldes y promueve el regreso de los poetas a la república platónica. «El filósofo busca porque se siente incompleto - escribirá en este libro - y necesitado de completarse, porque siente su naturaleza alterada y quiere conquistarla. Pero el poeta nada en la abundancia, en el exceso. $Y$ tal vez por esta sobreabundancia el poeta no puede elegir. Por vivir inundado por la gracia no puede recogerse sobre sí e intentar ser sí mismo, que es la obsesión del filósofo. Perdido en la riqueza, ciego en la luz. Pecador en la gracia, viviendo según la carne y según la caridad» ${ }^{25}$.

La citada M. ${ }^{\text {a }}$ Victoria Reyzábal se pregunta por qué María Zambrano no escribió poesía. Y ella misma responde que acaso sea porque defender esta razón agotaba sus fuerzas, o satisfacía sus necesidades, o le abrió un panorama insospechado, aún no asimilado en su complejidad, o toda su obra, funda-

24. Reyzabal, M. ${ }^{a}$ Victoria, Filosofía y poesía. Un «Cervantes» para la lírica liberada. En «Reseña», n. 192 (1989), p. 54. 64.

25. Zambrano, M., Filosofía y poesía. Fondo de cultura económica, Madrid 1987, p. 63- 
mentalmente ésta, es poesía, irradiante voz metafórica, eclosión de ensayo lírico revelador de verdades y bondades en cuanto la humanidad tiene, defiende, derrame, inventa la divinidad. "Toda poesía no es sino servidumbre - dirá más adelante en el mismo libro-, servidumbre a un señor, que está más allá del ser» ${ }^{26}$.

En el breve prólogo que escribe la autora en la nueva edición, desde Madrid, por el mes de febrero de este mismo año, dice con esa palabra suya, tan pensada como bella, que este libro, «nacido, más construido», lo fue en un momento de extrema imposibilidad; lo cual no le parece tan excepcional, «ya que no se pasa de lo posible a lo real, sino de lo imposible a lo verdadero» ${ }^{27}$.

Líneas adelante, escribe que «para no desanimar al siempre inverosímil lector», quiere contar un poco cómo nació en la ciudad de Morelia, capital del estado de Michoacán, en México, en un otoño de indecible belleza. Y explica cómo, a finales de la guerra de España, fue invitada para ir a Cuba como profesora de español. Ella había estado ya en esta república del Caribe, cuando se casó en 1936, como queda anotado páginas arriba. En Cuba el general Fulgencio Batista mandó detener el barco y encarcelar a toda la tripulación. María Zambrano y su marido se salvaron de la prisión gracias al pasaporte diplomático que llevaban.

Nunca olvidará al entonces «muy joven e inédito José Lezama Lima», poeta cubano que se refirió a los escritos que la escritora española había publicado en la «Revista de Occidente».

Pero la meta del viaje era Chile; concretamente, la ciudad de Valparaíso; y así, «a través de un largo y costoso periplo», hubo de pasar el canal dé Panamá. Un alma, como la suya, refinada y de poeta, rememoró el pasaje de «Pablo y Virginia», gozando del impresionante paisaje que se le ofreció al otro lado del Océano, en Balboa, justamente a la hora en que se ponía el sol.

Meses después, «cuando fue llamada a filas la quinta de mi compañero -escribe textualmente María Zambrano-, decidimos regresar a España en el momento en que era más evidente que nunca la derrota de la causa en que creímos. ¿Y por qué vuelven ustedes a España, si saben muy bien que su causa está perdida? Pues por eso, por esto mismo» ${ }^{28}$.

Filosofía y poesía fue escrito, precisamente, cuando, después de la derrota final, el matrimonio se encaminó a México. Lo escribió, pues, en el otoño de 1939 como homenaje a la Universidad de San Nicolás de Hidalgo, descendiente directo de los estudios de Humanidades, fundado por don Vasco de

26. Ibid., p. 111.

27. Ibid., "A modo de prólogo», p. 7.

28. Ibid., 1.c., p. 9. 
Quiroga ${ }^{29}$, no lejos de las orillas del lago Parzcuaro, que fue allí, desde España, a la región de los indios Tarascos, para fundar la Utopía de República cristiana de Tomás Moro.

A María Zambrano le parecía entonces «utópico» el escribir lo que ella llama «este pequeño libro», pues que «siendo irrenunciable en mi vida - dice- la vocación filosófica, era perfectamente utópico el que yo escribiera, y aun explicara, como lo hice, en la Universidad de San Nicolás de Hidalgo, Filosofía».

Ella entiende por Utopía «la belleza irrenunciable, y aun la espada del destino de un ángel que no conduce hacia aquello que sabemos imposible, como el autor de estas líneas ha sabido siempre que filosofía, ella, y no por ser mujer, nunca la podría hacer. Y la coincidencia se revela hasta en las palabras, pues en mi adolescencia alguien me preguntaba, a veces con compasión, a veces con ironía un tanto cruel, ¿y por qué va usted a estudiar filosofía? Porque no puedo dejar de hacerlo, y en éste he escrito, en aquel precioso otoño de 1939, que utópico me parecía, en el más alto grado, poderlo escribir» ${ }^{30}$.

Haciendo luego un análisis de su breve pero sustanciosa obra, dice que en esta nueva edición ${ }^{31}$ ha corregido a mano algunos capítulos sobre el ejemplar antiguo que ella conserva como regalo de la citada Universidad de Morelia.

El primer capítulo — «Pensamiento y poesía»-, acaso el más enjundioso, fue publicado, con mayor certidumbre, en la revista «Taller», fundada y dirigida por su, desde entonces, amigo y admirado Octavio Paz. Después, «en el momento de proseguir, ya se trataba de un libro, ya se trataba del ángel invisible e implacable que exige. Ya la forzosidad no servía, ya era sólo cuestión de vocación, de utópica vocación».

Alude luego a la segunda edición en «Obras reunidas», de la Editorial Aguilar, con una cierta seguridad por su parte y a la que esta edición no ha correspondido en modo alguno.

29. Vasco de Quiroga era natural de la histórica villa castellana Madrigal de las Altas Torres, y su fecha de nacimiento fue la del año 1470. Juez de la Chancillería de Valladolid, fue nombrado oidor de la Nueva España en 1530 y visitador de Michoacán. En 1534 se le concedió el obispado de esta diócesis. Inspirándose en La Utopía de Tomás Moro, fundó el «hospital», o comunidad indígena de Santa $\mathrm{Fe}$, en la que pretendía reinstaurar el cristianismo primitivo a partir de la moralidad natural de los indios. Fomentó, también, industrias locales en las principales ciudades del estado de Michoacán.

30. Zambrano, M., Filosofía y poesía. «A modo de prólogo», 1.c., p. 9-10.

31. Después de la primera edición, que apareció en México, en 1939, se hizo una segunda en Madrid, en 1971, por la editorial Aguilar, en la colección «Estudios literarios» y bajo el título de Obras reunidas, que comprendía, además de la obra objeto de nuestro estudio, El sueño creador, Apuntes sobre el lenguaje sagrado y las artes, Poema y sistema, Pensamiento y poesía en la vida española, y una forma del pensamiento: La Guía. 
Pero ahora renace en ella «el temblor del nacimiento, como si lo estuviera escribiendo de nuevo», y sólo se atreve a hacerlo por creer que lo nacido debe ser recogido, respetado. No pretende en modo alguno que se cumpla en ella ni en su libro la virginal virtud. Pero sí ve claro que vale más condescender ante la imposibilidad, que andar errante, perdido, en los infiernos de la luz.

Ella espera que el «eventual lector» la juzgue desde este ángulo. Espera que la juzgue el amor; y si de tanto no es todavía digna, que la juzgue al menos la compasión.

Breve libro, hermoso libro, que hasta en el mismo título - filosofía y poesía-, ofrece una aparente paradoja, muy al estilo del lenguaje empleado en sus obras por el maestro de Zambrano, Ortega y Gasset, a quien cita con frecuencia y sigue de cerca en sus reflexiones y comentarios sobre el pensamiento filosófico y la belleza del lenguaje poético.

A decir verdad, son pocos los mortales que han buscado conciliar estos dos términos, aparentemente, contradictorios: filosofía y poesía. Pues bien, «de estos pocos, sólo unos cuantos se han aproximado a la lucidez y al esplendor». María Zambrano es uno de ellos y lo prueba con claridad meridiana en este libro, en el que reflexiona precisamente sobre el tema enunciado en el mismo título, consiguiendo lo que le parecía imposible: ofrecernos el poder de su razón y la gracia de su poesía. Como leemos en contraportada, «aquí no hay triunfo del logos sobre el canto; su obstinado amor por ambos consigue la reconciliación. Fiel a su descripción de los orígenes de la filosofía, se sigue admirando y recreando sus sueños y sus fantasías sin necesidad de pisar tierra firme, sin renunciar a la diversidad». Por lo que nuestra escritora es un caso excepcional en el pensamiento español. Ella misma escribe en el primero, y para mí el más interesante de todos los capítulos, con palabras de Aristóteles, que «todos los hombres tienen por naturaleza deseo de saber». Mas, pasando por alto que, en efecto, todos los hombres necesiten este saber, se presenta enseguida la pregunta en que pedimos cuenta a la filosofía. ¿Cómo si todos te necesitan, tan pocos son los que te alcanzan? ¿Es que alguna vez la filosofía ha sido a todos, es que en algún tiempo el logos ha amparado la endeble vida de cada hombre? Si hemos de hacer caso de lo que dicen los propios filósofos, sin duda que no; mas es posible que más allá de ellos mismos, haya sido en alguna dimensión, en alguna manera... ${ }^{32}$.

Sobre «pensamiento y poesía», nuestra admirada ensayista comenta que, a pesar de que en algunos mortales afortunados poesía y pensamiento hayan podido trabarse en una sola forma expresiva, la verdad es que pensamiento y poesía se enfrentan con toda gravedad a lo largo de nuestra cultura. Cada una

32. Zambrano, M., Filosofía y poesía, 1.c., p. 23. 
de ellas quiere para sí eternamente el alma donde anida... Hoy poesía y pensamiento se nos aparecen como dos formas insuficientes; y se nos antojan dos mitades del hombre: el filósofo y el poeta. No se encuentra el hombre entero en la filosofía; no se encuentra la totalidad de lo humano en la poesía. En la poesía encontramos directamente al hombre concreto - escribe bellamente Zambrano-, individual. En la filosofía, el hombre en su historia universal, en su querer ser. La poesía es encuentro, don, hallazgo por gracia. La filosofía busca requerimiento guiado por un método... ${ }^{33}$.

Más adelante, reflexionando sobre «el mito de la Caverna», que se encuentra en La República de Platón, enseña que en este filósofo el pensamiento, la violencia por la verdad, ha reñido tan tremenda batalla como la poesía; se siente su fragor en innumerables pasajes de sus diálogos; diálogos dramáticos donde luchan las ideas, y bajo ellas otras luchas aún mayores que se adivinan; la mayor quizá, es la de haberse decidido por la filosofía quien parecía haber nacido para la poesía.

En todo caso, «Sócrates con su misterioso demonio interior y su clara muerte, y Platón con su filosofía, parecen sugerir que un pensar puro, sin mezcla poética alguna, no había hecho sino empezar. Y lo que pudiera ser una pura filosofía no contaba aún con fuerzas suficientes para abordar los temas más decisivos, que a un hombre alerta de su tiempo se le presentaban» ${ }^{34}$.

$Y$ es que el poeta, enamorado de las cosas, se apega a ellas, a cada una de ellas y las sigue a través del laberinto del tiempo, del cambio, sin poder renunciar a nada: ni a una criatura, ni a un instante de esa criatura, ni a una partícula de la atmósfera que la envuelve, ni a un matiz de la sombra que arroja, ni del perfume que expande, ni del fantasma que ya en ausencia suscita.

De no tener vuelo el poeta - sigue comentando más adelante en su libro-, no habría poesía, no habría palabra. Porque toda palabra requiere un alejamiento de la realidad a la que se refiere; toda palabra es, también, una liberación de quien la dice.

La poesía - termina este hermoso capítulo- no es polémica; pero puede desesperarse y confundirse bajo el imperio de la fría claridad del logos filosófico, y aun sentir tentaciones de cobijarse en su recinto. Recinto que nunca ha podido contenerla, ni definirla.

El resto de los capítulos de Filosofía y poesía, con ser todos ellos interesantes, ofrecen, a nuestro modesto modo de entender, menor interés. En el que reflexiona sobre el tema poesía y ética, vuelve a La República, de Platón, para decirnos que de Grecia nos vino la luz y, así, todo lo que en ella acontece

33. Ibid., 1.c., p. 13.

34. Ibid., p. 19. 
se presenta con una claridad deslumbradora, lo cual no quiere decir que vayamos a entenderlo sin esfuerzo, ni tan siquiera que lo entendamos. Pero percibimos enseguida que es plenamente inteligible.

En Grecia, insiste, vemos que el optimismo, la esperanza se abrió paso por la vida del pensamiento. La razón, el hermosísimo descubrimiento griego correlativo al ser, era libertadora. Razón y esperanza iban entonces juntas. La contraposición que después, en el mundo cristiano, se ha realizado entre razón y esperanza, entre razón y fe, pretendiendo extenderla hasta el nacimiento de ambas, es por completo infundada y constituye un error de perspectiva. Cuando nació la razón en los hermosos días de Grecia fue la depositaria, el vehículo de la esperanza y así aparece espléndidamente en Platón ${ }^{35}$.

Por contra, el pesimismo se encuentra en la tragedia, en el mundo de los dioses despiadados. «Humanos, demasiado humanos estos dioses tenían cercado al hombre, en realidad. Le atajaban su paso, le vigilaban y oprimían. ¡Pobres hombres bajo el terror de tanta divinidad celosa, vengativa, de tanta justicia despiadada! Justicia también la de los dioses, pero justicia divina, es decir, irracional, puramente vindicativa. El hombre era menos que los dioses y tenía, en consecuencia, que ser arrollado por ellos».

Al final de este capítulo, María Zambrano se pregunta: pero ¿no tendrán -poesía y poeta - su justificación, su propio reino? ¿No habrá en todo el universo, en ese universo que el poeta ama tanto y con tanto fuego, ningún sitio para él? ¿Más allá de la justicia, no habrá nada para el poeta? El poeta no pide, sino que entrega; el poeta es todo concesión. ¿No le será concedido nada?...

Un tercer capítulo lo dedica a divagar sobre los términos y significado de «Mística y poesía». Y es que la poesía - según ella - ha sido en todo tiempo un vivir según la carne. Ha sido pecado de la carne hecho palabra, eternizado en expresión, objetivado. Nuestra eximia escritora vuelve, yo diría, a su filósofo preferido, a Platón, al diálogo La República, y de nuevo al «mito de la Caverna»; también al Fedón, donde la filosofía queda establecida clara y taxativamente como «sabiduría de la muerte». ¿No es verdad - se pregunta con palabras del Fedón- que el sentido preciso de la palabra muerte es que un alma se separa y se va aparte de un cuerpo? Ciertamente. Y que esta liberación, como decimos, los únicos que la procuran son aquellos que en el sentido recto del término se ocupan en filosofar. El objeto propio del ejercicio de los filósofos ¿no es este mismo de liberar el alma y separarla del cuerpo?».

El poeta siente la angustia de la carne, su ceniza, antes y más que los que quieren aniquilarle. El poeta no quiere aniquilar a nada sobre todo de las co-

35. Ibid., c. II, «Poesía y ética», 1.c., p. 31. 
sas que el hombre no ha hecho. Rebelde ante las cosas que son hechura humana, es humilde, reverente con lo que encuentra ante sí y que él no puede desmontar: con la vida y sus misterios... Eterno enamorado, nada exige. Pero su amor lo penetra todo lentamente...

Agradezcamos a Platón -escribe Zambrano-El Banquete, El Fedón. Por ellos el amor quedó a salvo de su total destrucción. Mas no podía faltar a la cita, en este bello capítulo, san Juan de la Cruz y su Cántico espiritual, que es el canto a la ausencia del amado; aquí explicable porque su amado, en efecto, no es visible. «Pero en la poesía profana de este tiempo - escribe textualy del anterior se vería también constantemente este motivo de ausencia y de búsqueda constante de las huellas del amado, la naturaleza entera se transforma: ríos, árboles, prados, la luz misma conserva la huella de la presencia amada siempre esquiva e inalcanzable... Poesía platónica en la que se perpetúa la antigua religión del amor, la antigua religión de la belleza transformada, a veces, en religión de la poesía» ${ }^{36}$.

Tal vez le haya fallado a la insigne ensayista malagueña la cita oportuna del «príncipe de la lírica hispana», poeta excepcional y poeta místico, poeta neoplatónico, como discípulo de san Agustín, llamado Fray Luis de León. Tal vez se le haya escapado la cita de alguna estrofa de su bellísima Oda a Sálinas, o de la que se titula De la vida del cielo, y que comienza «alma región luciente,/ prado de bienandanza...», aunque siga en pie la eterna polémica sobre si el Mtro. León puede ser considerado verdadero místico o no.

En el último capítulo de Filosofía y poesía, titulado sencillamente «Poesía», Zambrano vuelve a jugar a la metáfora con los términos «filosofía y poesía», para decirnos que «filosofía es encontrarse a sí mismo, llegar por fin, a poseerse. Llegar a alcanzarse atravesando el tiempo, corriendo con el pensamiento más que el tiempo mismo; adelantándose a su carrera en una competencia de velocidad... Ninguna ambición más seria, más profunda y por ello, quizá, más reprobable que la filosofía. Quiere el filósofo salirse de la corriente del tiempo, de la procesión de los seres, despegarse de la larga cadena de la creación en que marchamos unidos en condena temporal con los demás, con el resto de los hombres y con las otras criaturas también: luces y sombras que nos acompañan» ${ }^{37}$.

¡Qué belleza de lenguaje ${ }^{38}$ cuando escribe que «el poeta antes que nada y

36. Ibid., c. III, «Poesía y mística», 1.c., p. 69-70.

37. Ibid., p. IV, «Poesía», l.c., p. 101ss.

38. En nada pierde su belleza de lenguaje y, sobre todo, su contenido, la mala puntuación de signos de ortografía y especial sintaxis que echamos de ver en este libro, al igual que en Delirio $y$ destino que hemos de estudiar en páginas posteriores. Es evidente que no se debe emplear por igual «el punto y coma» - por ejemplo-, que «la coma», o los «dos puntos». Y mucho menos, 
ante todo, es hijo. Hijo de un padre que no siempre se manifiesta. Lo hemos definido como amante, anteriormente, pero la verdad es que antes que amante es hijo, o más verdad todavía: es el hijo amante, el amante que une en su ilimitado amor el amor filial con el enamoramiento. Filial, porque se dirige hacia sus orígenes, porque todo lo espera de ellos y por nada está dispuesto a desprenderse de lo que le engendrara. Y enamorado, porque está absorto en ello con las mismas exigencias, las mismas locuras y desvaríos del amor de los amantes. Baudelaire, mártir de la poesía, iqué claramente lo muestra!».

Creo que vale la pena terminar esta glosa sobre Filosofía y poesía, citando una estrofa de san Juan de la Cruz, en donde se echa de ver cómo el amor le ha hecho salir de sí mismo al poeta, sin poder ya recogerse jamás, perdiendo su existencia y ganando la total aparición, la gloria de la presencia amada; si bien, el autor del Cántico espiritual no se está refiriendo al poeta como tal, sino al alma y a la unión de ésta con el Amado:
«Pues ya si en el ejido
de hoy más no fuere vista ni hallada, diréis que me he perdido, que andando enamorada, me hice perdidiza, y fui ganada» ${ }^{39}$.

\section{GLOSA Y COMENTARIO AL LIBRO: DELIRIO Y DESTINO \\ (Los veinte años de una española)}

«Aunque escribí este libro a principios de los años cincuenta - dice la autora-, quiero mostrar mi gratitud a la Fundación María Zambrano de Vélez-Málaga por haberme dado serenidad y tiempo para sacarlo ahora a la luz debidamente actualizado».

Cuando apareció este nuevo libro de nuestra ilustre ensayista y pensadora, la crítica y la propaganda se apresuraron a ponerle el remoquete de novela. $Y$, la verdad, uno lo lee con sumo gozo por su belleza de lenguaje, pero no sabría decir hasta qué punto puede ser incluido entre lo que entendemos por el género narrativo ${ }^{40}$. Enseguida advertimos que esta obra es algo más que una

no saber cuándo se debe poner el «punto y seguido», y el «punto y aparte». En ocasiones, me he atrevido a corregir alguno de estos signos, respetando siempre y literalmente el texto; y otras muchas, me he quedado con las ganas, debido a ese profundo respeto y admiración hacia nuestra insigne escritora. p. 18.

39. SAN JuAn DE LA CRUZ, Cántico espiritual, estrofa 20. Ed. Orbis, S.A., Barcelona 1982,

40. Zambrano, M., Delirio y destino. (Los veinte años de una española). Ed. Mondadori España S.A., Madrid 1989. 
simple novela; o mejor, que tiene mucho más de libro autobiográfico, que de novela propiamente dicha.

Por lo que, leyendo más tarde el juicio que de este libro hace Francisco Solano, me parecieron muy acertadas sus palabras. No cabía esperar - dicede María Zambrano una novela al uso. Delirio y destino, pese a venir aureolada con el membrete de «única novela de María Zambrano», difícilmente, a costa sólo de una concepción arbitraria, puede ser considerada como tal.

Es cierto que el género narrativo, dentro de la literatura universal, es bastante elástico y hasta híbrido y absorbente; por lo que bien puede ser incluido el libro de María Zambrano en el mismo. Pero, como apunta muy bien el crítico citado, la escritura misma de su autora, su peculiar sintaxis ${ }^{41}$, su sentido de la palabra no se aviene bien a quedar encerrada en una estructura novelesca. De hecho, Delirio y destino participa más de la autobiografía, del ensayo biográfico, o de las memorias, que de la novela en su sentido estricto.

Tal vez estaría mejor traer aquí las palabras de la propia Zambrano, cuando enseña que el género literario «no es sino un método de que la vida se libre de sus paradojas y llegue a coincidir consigo misma».

Uno entra en la lectura de este libro - que tiene más de poético, que de narrativo- y desde las primeras páginas reconoce en ella a la protagonista del mismo: a esta mujer singular, andaluza de Vélez-Málaga, española cien por cien, universitaria y fiel seguidora de su maestro Ortega y Gasset, dotada de un alma exquisita y de una sensibilidad tan fuera de lo común, que nos hace ver hasta en lo más oscuro y recóndito de la razón la poesía que encierra la vi$\mathrm{da}$, el hombre, el mundo, las cosas...

Delirio y destino -(Los veinte años de una española) - «quiere ser la introspección a una vida que, expuesta como núcleo de una realidad histórica, se universaliza hasta alcanzar una reflexión más vasta que incluye, no sólo a la España de los años treinta - los años de juventud de María Zambrano-, sino también a la Europa convulsionada de aquellos años» ${ }^{42}$.

Escrito este libro en la Habana a principios de 1950, «ella», nuestra María Zambrano, retrocede en la historia de su vida, se incorpora de nuevo a las aulas de la Universidad Central de Madrid, rememora el grupo de intelectuales que fueron sus profesores, sus amigos, los que anhelaban hacer «cosas serias», pero «con alegría» y como en una introspección a la vez histórica y soñada, encarna de nuevo para sí misma «las múltiples metamorfosis interiores,

41. Esta misma obervación, «de peculiar sintaxis», la acabamos de hacer notar en el comentario de Filosofía y poesía. Cf. nota, n. 38.

42. Solano, Francisco, Delirio y destino. La historia de un sueño. En «Reseña», n. 196 (1989), p. 41. 
las corrientes anímicas, los sentimientos, la esperanza, el delirio, en suma, de su persona, convertida al cabo, merced a su anhelo de ser, en memoria viva de un país, de una época, pero no en cronología ni en suceso noticiable».

«Ella», la protagonista de Delirio y destino, ha dejado escrito que «vivir humanamente debe ser ir sacando a la luz el sentir, el principio oscuro y confuso, ir llevando el sentir a la inteligencia»" ${ }^{43}$. Y eso es, precisamente, lo que hace en este libro: desde el profundo sentir de su clara inteligencia, muestra su excepcionalidad y la fortaleza de su sueño, para hacer palpitar el corazón y recobrar el alma, la verdadera dimensión de lo vivido.

María Zambrano, aunque hace historia de la España de su juventud -de los años de la dictadura de don Miguel Primo de Rivera, sobre todo-, rehúye el dato, el acontecimiento concreto, para fijarse en el verdadero protagonista de la historia, que es el hombre - según expresión gráfica y feliz de Arnold Toynbee-, en «la intrahistoria» unamunesca, ya que, para ella, «la imagen de la marcha sucesiva de la Historia es un error, como lo es toda imagen simplificada».

A María Zambrano, como a Unamuno años atrás, «le duele» la España de su tiempo; pero se recrea en ella - un Madrid en el dorado otoño-, porque espera, al estilo de su gran amigo Antonio Machado «una nueva primavera».

Nadie mejor que María Zambrano ha sabido reunir en su voz, en un solo haz de armonía - como ha quedado comprobado en páginas anteriores-, la reflexión filosófica y la intuición poética. Pues bien, Delirio y destino, quizás el libro más accesible de todos cuantos ha publiado al común de los lectores, trata de explicar la causa de esta voz única y el esfuerzo por hacerla pervivir más allá de las humillaciones de la historia.

En muchas de sus obras nos recuerda que escribir es defender la soledad en que se está, desde un aislamiento efectivo, pero también desde un aislamiento comunicable. Pues bien, si algún libro expresa en todo su rigor el profundo significado de estas palabras es Delirio y destino. Y ello, porque es la imagen viva, precisa y global de una escritura, y supone, a la vez, la recuperación de una imagen donde la autora conjuga su propia vida, proyectada en los hechos y la distancia del personaje literario.

Este libro quiere ser la expresión de «los veinte años» de una mujer preocupada, ya entonces, por los problemas de España, la España de los años anteriores a la guerra civil, de la que María Zambrano no escribe ni una sola página en este libro; los veinte años de una mujer intelectual, universitaria, alumna de Ortega y de Zubiri, y profesora luego de sus mismas asignaturas;

43. Zambrano, M., Delirio y destino. Ed. Mondadori 1989, p. 93. 
los veinte años de una mujer inquieta, que ha heredado las ideas liberales y republicanas de su padre, y que se agrupa en torno a la idea esencial de una España decadente y dormida, a la que era preciso despertar, como en los días del desastre nacional del 98.

Por eso está tan presente el nombre y là realidad de España en Delirio y destino. España aparece, ante todo, en estas páginas «como un anhelo de libertad». Pero no debe olvidarse que, como certificara hace tiempo Gabriel Marcel, nos hallamos ante un texto que, al expresar la vida en un ámbito tan significativo como el de un continente en guerra, se transforma en una memoria de Europa, con significativas implicaciones autobiográficas que alcanzan un valor pleno en nuestro presente.

A la misma María Zambrano le parece imposible presentar este libro, inédito en su mayor parte, después de cerca de cuarenta años en que fuera escrito; y más imposible y prodigioso todavía el que se publique ahora.

Efectivamente, como queda apuntado en otro lugar, Delirio y destino fue escrito en la Habana, al comienzo de los años cincuenta, con ocasión de un premio literario que promocionaba el «Institut Europeen Universitaire de la Culture», con sede en Ginebra.

El citado filósofo francés Gabriel Marcel, miembro del jurado, no pudo disimular su disgusto, cuando comprobó que el premio no había recaído sobre esta obra; y así lo expresó públicamente. Este libro de María Zambrano se merecía el primer premio «no sólo por su calidad, sino también porque era la historia de Europa y de lo que significaba la universalidad de España». Delirio y destino tuvo que contentarse con una «mención de honor».

La autora de este hermoso libro irrumpe en él, que es lo mismo que decir en su vida, con dolor. Ella habría querido morir, pero no al modo en que se quiere cuando se está lejos de la muerte, sino yendo hacia ella.

Porque se puede morir aún estando vivo. Uno se muere de muchas maneras. Por ejemplo, se muere en ciertas enfermedades, en la muerte del prójimo, «y más en la muerte de lo que se ama y en la soledad que produce la total incomprensión, la ausencia de posibilidad de comunicarse, cuando a nadie le podemos contar nuestra historia» ${ }^{44}$.

El maestro Ortega había dejado escrito que «vivir es convivir»: pero cuando la convivencia es imposible porque el que convive interpone y echa su juicio sobre la persona, sobre aquella que nace solamente cuando se comparte, es la muerte. Se muere juzgado, sentenciado a aislamiento por «el otro».

Glosando a Calderón de la Barca, Zambrano se pregunta si somos sombras de sueño; sombras del sueño de Dios. «Mi vida - dirá- no es mi sueño y

44. Ibid., 1.c., p. 16. 
si la sueño, es porque yo que la sueño soy soñado. Dios nos sueña y entonces hay que hacer que su sueño sea lo más transparente posible, reducir la sombra a lo menos, adelgazarla».

Como hijos del sueño - escribe más adelante-, nacemos de un sueño, del sueño de nuestros padres, del sueño de la naturaleza toda, del sueño de Dios... La tragedia única es haber nacido. Pues nacer es pretender hacer real el sueño. Nacer es realizar o pretender realizar el sueño de nuestros padres; el sueño de Dios inicialmente. Quizá Dios soñó con una criatura, su predilecta; quizá el Universo nos sueña como su cumplimiento y estamos ya soñados, presoñados en la flor y en el árbol que se yergue, en la misma materia extensa, soñada también, ella que aspira a la realidad y sirve para alcanzarla...

Para «ella», la vida había comenzado desde algo. Siempre lo había sentido; y ahora - al tiempo de escribir - comprendía el sentido de aquella cita en la noche, hacia la que corría desde niña, porque entonces era la noche pura, tan larga... Estaba aquí de nuevo, después de haberse alejado de todos, de todo, hasta que se vio a sí misma... ${ }^{45}$.

Había llorado por querer lo que no querían; darle, por querer a quien no le quería... Había llorado desde niña reprochándole a la vida por haberla dado tanto, «por haber sido demasido rica y colmada de ternura y amor...; por haber vivido en aquellos jardines maravillosos con la nostalgia siempre de otro lugar más encantado, su Andalucía natal quizá, dejada atrás tan pronto; y sólo encontraba la calma, cuando a solas en su cuarto, o en el jardín, o entre la gente, sentía aquella presencia no sabía qué; se sentía mirada, vista desde lo alto, esto es, lo más cerca a la verdad, más libre de interpretación...

Mas llegó un momento en que se había vaciado de sí misma y ya no se dolía; había perdido su imagen y esto era un gran descanso. Es curiso observar cómo mientras el «personaje» crece y toma posesión de cuanto espacio vital le dejan, sus semejantes, la persona que lo sustenta se vuelve como un fantasma.

«Ella» lo había descubierto así: quería ser fiel a aquella desnudez en que se vio; su verdad. La persona, para ella, eso intangible, indestructible; mientras que toda imagen puede ser destruida y es por esencia transitoria. «Y sin embargo, no hay amor que no cree una imagen, que no se alimente de ella y no se dé al mismo tiempo como en sacrificio».

Nuestra eximia y exquisita escritora va discurriendo, páginas adelante, sobre el amor; el amor que busca la identidad...; un amor que si va a ser compartido, vivido, hay que soportar la vida de lo que se ama..., y si no, todo se hace más fácil como lo fue al fin para don Quijote, para Dante, para todos los grandes estrategas del amor que supieron ser esclavos, siendo en verdad libres, es decir: ganar voluntad.

45. Ibid., p. 21. 
«Ella», María Zambrano, veinte años, había asistido - lo hemos visto en su biografía-, sin perder apenas una, a las clases de metafísica con Ortega, «de tan deslumbrante claridad...». Era tan claro y, sin embargo, apenas había entendido alguna cosa. Un curso, todo un curso sobre la Crítica de la razón pura, de Kant.

En el capítulo que titula «Recordando el futuro», jugando con la paradoja, vuelve sobre sí misma y ve cómo no había estado casi nunca sola, salvo en aquel momento en que no pudo morir. «Sólo ciertas compañías humanas la dejaban aislada, más que sola, y por eso le resultaban insoportables».

Deseaba entonces vivir en la verdad; en una verdad viviente que invade al hombre y está en nosotros. De aquellos años, recuerda, cuando tenía los veinticuatro de su edad, que formaba parte del grupo de intelectuales a los que nos hemos referido anteriormente, los cuales deseaban «ser serios del modo más alegre». Recuerda, asimismo, cómo en la charla que tuvo que dar en el ateneo de una ciudad de provincia - acaso Valladolid-, había hablado con voz opaca y no había podido comer en todo el día. No había dado importancia a su estado febril, atraída solamente por un foco: ESPAÑA.

¡Con qué amor y pasión habla María Zambrano de la FUE (Federación Universitaria Española) ¡Bastaron unas palabras cruzadas como signos rápidamente, para que algo nuevo surgiese entre ellos: «un entendimiento fraternal». Recuerda la visita del grupo a don Manuel Azaña, el cual les recibió «en una habitación llena de libros con apenas unas sillas». Y cómo a la pregunta del político: ¿Pues qué quieren ustedes?, ellos contestaron: «-Eso ha de decirlo España. Nosotros sólo queremos que despierte, porque ya está despierta; que entre en la vida, porque ya ha dejado de estar muerta. Queremos... una moral, una vida para todos» ${ }^{46}$.

Don Gregorio Marañón, sin duda el personaje más brillante de aquella hora, tampoco acababa de entender y menos comprender a este grupo que le parecía un tanto romántico. A su petición de ayuda por la causa, respondió:

-Yo trabajo sin tregua - les dijo-. Sólo soy un francotirador.

- Pues tendrá usted que bajar de su árbol al llano - le contestaron-, para marchar juntos. Hay que estar juntos.

-Pero ustedes son unos niños y quieren estrenar la historia de España; replicó el célebre y memorable escritor español.

- ¿Por qué no, don Gregorio?... Le dijeron con aplomo...

«Ella», María Zambrano, recordaba, otra vez, la frase espléndida del maestro Ortega: «Vivir es convivir». Para ella y para los demás del grupo, esto debía ser lo nuevo; esta ansia de convivencia profunda, de integración, de orden; este dar la cara a las «circunstancias»; siempre en lenguaje orteguiano.

46. Ibid., p. 42. 
España, en aquella hora difícil -1929-, no podía negar ya por más tiempo el pensamiento que sobre ella se había ido vertiendo. España, que había tenido siempre sangre en demasía, exceso de sangre, tenía que dejarse oír.

Aquel grupo de jóvenes, sin haber leído a Spinoza - «ella», María Zambrano, sí le había leído-, quería a España así, con alegría. «Era, fue un crimen -escribe literalmente-. Como tal habrían de pagarlo; con su sangre, con su muerte, con su vida».

Recuerda, ahora con gozo, las dos pequeñas secciones que les habían concedido los periódicos «El liberal», y «La Libertad»; adscribiéndola a ella a la sección «Aire Libre», del primero de los citados, donde le obligaron a firmar; cosa que a María Zambrano le desagradaba.

En este hermoso - tan hermoso como utópico- empeño, lo único que deseaban era servir «como la conciencia sirve a la vida»: recogiéndola, unificándola. Por eso habían decidido acercarse hasta el mundo obrero, y hablar con él con simpatía y respeto; con los socialistas, con los anarquistas, para sacarles acaso de su mentalidad romántica de lectores de novelas históricas y trasnochadas; sacarles de la violencia, rescatar su autenticidad ancestral; pues adivinaban en ellos un tesoro de hombría, de salud, de ingenuidad, de fe preciosa...

Otro de los recuerdos más gratos se lo dedica a los poetas de la «generación del 27»: a García Lorca y enseguida, como la estrella gemela, a Rafael Alberti. «QQué alegría pura, como del alba!, cuando apareció Marinero en Tierra, premiado al mismo tiempo con el premio nacional de literatura que un libro de Gerardo Diego ${ }^{47}$. Y Jorge Guillén y Pedro Salinas - «Entrada en Sevilla»- en prosa, publicada en los primeros números de la «Revista de Occidente», tan clara, tan nítida, tan precisa. El idioma castellano se adelgazaba, se convertía en cristal y dejaba ver sus puras entrañas. ¡Qué idioma tan bien nacido!...» ${ }^{48}$.

Al final de este hermoso capítulo, la esperanza del renacer cada día se vislumbra con claridad. «Ya la luz nos aguarda. Ya está ahí comenzada la historia que haya que proseguir. Despertar es entrar en un sueño ya en marcha, venir desde el desierto puro del olvido y entrar, lo primero, en nuestro propio cuerpo, recordarlo sin rencor, entrar a habitarlo y recuperar nuestra alma, con su memoria y nuestra vida, con su quehacer. Entrar como en un capullo

47. Rafael Alberti consiguió el premio Nacional de Literatura, con su bello libro de poemas Marinero en tierra, el año 1925. En cuanto al libro de Gerardo Diego, publicado en aquel mismo momento, pensamos que se trata de Versos humanos, en el que se encuentra, entre otros poemas, el célebre soneto, de corte clásico, dedicado «al ciprés de Silos».

48. Zambrano, M., Delirio y destino, 1.c., p. 60. 
tejido por innumerables gusanos afanosos; retomar nuestro hielo en el capullo fabricado incansablemente por el gusano-hombre, hacedor de ensueños que se objetivan, fabricador de historia».

Si, como diría Calderón de la Barca - a María Zambrano le gusta divagar sobre la obra cumbre del dramaturgo español-, la vida humana es sueño, sueño de alguien, debemos tener con él alguna semejanza, puesto que soñamos también, soñamos nuestro inacabado ser de muchas maneras, en la poesía ante todo, en todo arte, y en la acción, hasta en la técnica hay ensueño.

España, en aquellos años (1929), según nuestra escritora, despertaba soñándose. Todos los españoles de aquella hora, de modo especial los que habían asistido a las escuelas, institutos y universidades, los españoles que pudiéramos llamar letrados, habían crecido con el amargo sabor de la decadencia española, mezclado al orgullo ancestral de la grandeza y a un cierto vislumbre de que esta grandeza había sido malbaratada.

María Zambrano afirma en Delirio y destino que, desde el siglo XIX, se había ido intensificando y ensanchando la conciencia de España, del conflicto de ser español. Y cita al granadino Ángel Ganivet, suicida, como Larra, pero medio siglo después que aquél, en el momento histórico de 1898, «por enfermedad dice, sí, por enfermedad de España».

Coloca frente a frente a Menéndez Pelayo, el historiador católico a ultranza, enumerador en una especie de libro sagrado de la ciencia y la filosofía española, y a Galdós, el novelista enumerador de la España sub-histórica, de las entrañas que quedan bajo el vivir histórico.

La España que le toca vivir a María Zambrano al comienzo de la década de los años treinta podía resumirse en esta lacónica frase: « ¡Hambre y esperanza!». España tenía el hambre y la esperanza contenidas, aguantadas desde siglos, los siglos de esa famosa decadencia...

En aquel momento contaban los catalanes y los vascos, unidos tan sólo por analogía de sus reivindicaciones frente a la ley, a la vieja ley castellana que ellos decían sentir como opresión. En cuanto a la esperanza, se la habían ido desatando sobre todo los disidentes, los inconformes de la España oficial, los que buscaron la cura y el remedio a ese su sentir de víctima de la historia, del yerro propio y de la injusticia ajena.

En el hondón de los recuerdos, está presente Giner de los Ríos, fundador de la «Institución Libre de Enseñanza», en medio de un ambiente espiritual del krausismo. También está presente el «Señor Cossío», por encima de todo enigmático, «elegante de espíritu y presencia, guardador de algún secreto último de su sabiduría que nunca entregó». Igualmente, acude a la cita -icómo no! - Pablo Iglesias, alma creadora del Partido Socialista Obrero Español, «factor muy decisivo en esta dialéctica de la esperanza». Y Julián Besteiro, ca- 
tedrático de lógica de la Universidad de Madrid, «institucionalista, de cuya persona emanaba una profunda bondad».

Sin embargo y a pesar de todos estos nombres ilustres, España se quedaba sola. Nunca lo había estado, toda vez que el mismo año que lograra su unidad nacional en tiempo de los Reyes Católicos descubrió el Nuevo Mundo. En este momento de su historia, «se quedaba sola consigo misma, como.la madre cuando todas las hijas se han casado. ¿No era el momento de meditar? Sola e incomprendida; sola y mal dentro de sí, como una madre pobre y medio loca»".

Meditadores fueron los hombres del 98, más que por el contenido de su obra, por su actitud. «Meditaron sobre la menuda realidad minuciosamente y con una voluntad de conocimiento. Tal vez, el más meditador fuera Ramiro de Maeztu, vasco andariego en su juventud por Inglaterra y.Estados Unidos. Pero la lección de meditar sobre España comenzó en Unamuno, con sus ensayos por los años ochenta. Le siguió Ángel Ganivet, de su misma generación, y en tantas cosas su complementario, el cual muestra en su Idearium Español una España conflictiva.

«Ella», María Zambrano, había comenzado a leer muy pronto a Unamuno, la voz que clamaba en aquella hora de la «Restauración». «Nadie había clamado así en España nunca, y nadie desde Quevedo quizá hablaba de ese modo, sin inhibición, casi sin pudor». Pero sería leyendo al maestro Ortega cómo sentía ganas de seguir viviendo. Con su lectura, se veía que la vida era cosa buena, inteligente de por sí; que la vida era razón y la llevaba consigo, su profunda razón. Y eso era amar la vida, querer vivirla con fe, esperanza y alegría.

Zambrano termina este bello capítulo de la España, que despertaba soñándose, con un párrafo que respira optimismo: «El aire era transparente - dice-_en España. Había visibilidad y quien mirase. Por eso, de repente se atravesaba en el ánimo una congoja, más por lo de fuera, que por lo de dentro... La polémica de Unamuno contra el progresismo europeo había quedado rezagada; ni él mismo se acordaba ya. El pensamiento había curado la herida de la incomprensión. Y había, seguía, habiendo heridas; eran las nuestras propias y también las de Europa; porque sus heridas eran también y, sobre todo, su preocupación» ${ }^{49}$.

Nuestra pensadora e insigne ensayista, después de una grave enfermedad, con veintiséis años cumplidos, aceptaba la vida y la amaba. De las lecciones de Ortega creía haber sacado la conclusión que hay algo, en el joven, más importante que el valer, que es el ser. Por eso, se sentía agradecida al maestro. «Y en

49. Ibid., p. 89. 
medio de la angustia sintió que despertaba, que iba a despertar de nuevo, a despertar... ensoñándose. $\mathrm{Y}$ entonces tenía que disponerse a vigilar su sueño. El suyo, sola, del que sólo podría responder, ¿pero era posible?...».

Y como ella, España. La España despojo de la historia universal; la España real, de carne y hueso; pueblo, pueblo que aguantaba el hambre y la esperanza; que daba signos de despertarse, olvidándose de su historia anterior, de la universal.

En el capítulo que titula «La multiplicidad de los tiempos», se pregunta por qué los místicos, como Teresa de Jesús, lograron abstraer el tiempo casi enteramente, vivir en dos tiempos o en tres. Y se responde a sí misma que quizá fuera porque ella, Teresa, vivió el «instante» en el éxtasis, el tiempo histórico en su acción en el mundo, entre el mundo; y vivió también el tiempo de la meditación.

Nuestra joven universitaria huía del tiempo humano. Le parecía no haber hecho otra cosa que huir de lo humano, retroceder desde el tiempo sucesivo donde se dan las obligaciones, la atención al prójimo; más aún, el tiempo que es un pacto, o fruto de un pacto, después de haber probado la soledad. Para terminar declarando que cada época y, dentro de ella, cada generación tiene su marcha, su ritmo que arrastra y uno va donde sea, porque el caso es marchar juntos, marchar con, hasta la muerte.

«Ella» se quedó sin hacer la novela de la multiplicidad de los tiempos, especie de viaje del alma asistida de la conciencia. Entretanto, siguiendo la marcha, el ritmo acompasado de su vida, hubo de volver a la ciudad. Los compañeros se habían dispersado y la configuración de la vida juvenil era muy otra. Dentro de la Federación Universitaria, habían surgido grupos activos, sin más organización que la necesidad de la acción traía consigo; y esta acción era poética, enteramente inventada. Y por ello, constante. No se proyectaban actos políticos. Aquello era algo más serio y más grave: «se estaba creando un ambiente, una atmósfera que iba envolviendo a la vida de la ciudad y de otras ciudades de España».

Concretamente en Madrid, que aún tenía un paisaje norteño siempre verde, que tenía aún ese aspecto desastrado que han de tener las ciudades orientales que guardan un esplendor dentro, aunque luego el esplendor no se encuentra ya en él, María Zambrano recordaba ahora los años de su niñez, las terribles tardes del domingo y las más terribles todavía de los días de fiesta. «Le había quedado en el oído el arrastrarse de los pies sobre las aceras, los brazos caídos, las caras vacías, como si la vida pesara tanto, y no la vida, sino el peso de un vacío que impedía los movimientos y los hacía como inútiles, el peor de los cansancios».

En esta hora crucial de su vida, se define como «una universitaria, pero no una intelectual», que deseaba «servir anónimamente a otros, a todos, y es- 
tos todos eran en primer lugar, «los que han hambre y sed de justicia y de pan»; que deseaba compartir el pan y el alma...

Ignoro si por estas fechas, nuestra escritora conocía a san Agustín y había leído sus Confesiones. Pero leyendo las páginas que siguen de Delirio y destino, da a entender que lo conocía y que, como él, deseaba «amar y ser amada». Lo que ella quería, como el obispo de Hipona, era vivir la vida verdadera; y, sin atreverse a llamarla así, la buscaba con ardor. «Porque se sentía llena de aurora. La vida con tal de que estuviera abierta a un horizonte no trazado por geómetra humano, la vida misteriosa y clara, hija del número de una matemática infinita, como la realidad, que si no era inagotable, no podía amarla».

Es entonces cuando se incorpora a su cátedra en el Instituto Escuela. Era su única obligación, pero tan fascinante, que el cumplirla, no le dejaba ninguna huella de esfuerzo; no era un trabajo, y como no sentía que lo fuera, trabajaba, trabajaba de verdad.

Hay momentos en que se siente del todo feliz; de modo especial, en aquel otoño, «que tiene también su verano, ese minuto en que se incendia su oro y se convierte en fuego», en que vino la amistad hacia ella, la amistad de aquellos compañeros que acudían los domingos a su casa por la tarde, y ella les preparaba, solícita y amorosa, una taza de te.

«Ella» mataba el tiempo visitando el Museo del Prado, que tenía algo de templo. Con particular atención, evoca el comienzo del curso 1930, en el que las huelgas de los estudiantes se sucedían con intensidad creciente, y con los que estaban la mayor parte de los catedráticos, al menos los más representativos de la Universidad.

En esta coyuntura histórica no queda bien parada la figura del dictador Primo de Rivera, que, por otra parte, no tenía mala fe, sino que se había condenado simplemente, por servir, por prestarse a recubrir un vacío. Y entró en polémica con los estudiantes y con los intelectuales.

En aquella hora histórica, la luz de Madrid vibraba más que nunca. Era ligera y carnal. Se hacía presente. Era un cuerpo luminoso. Como «ella» no pertenecía a ningún partido político, y era únicamente ayudante de cátedra de historia de la filosofía, sólo se concentraba en el trabajo que estaba realizando. «Desde la raíz de su vida, la filosofía había sido, «a falta de otra cosa», la única manera, la solución única de vivir sin esas cosas, sin traicionarlas, de obedecer en esta libertad que deja el no ser nadie, de ser «uno más».

Cuando, dos años más tarde, lea a Bergson, sentirá una inmensa alegría, la alegría de que era posible rescatar la música perdida, pues él, Bergson, la hacía al mismo tiempo que hacía filosofía; hacía música con su pensamiento, porque era preciso. Había hecho de la precisión la virtud esencial de su pensamiento, sustituyendo con ella a la «clarté» cartesiana - pensaba ahora María Zambrano-y lo que es preciso tiene música; es música. 
Una mañana, los españoles supieron por la prensa que se había ido el Dictador. En su lugar quedaba otro general ${ }^{50}$. El Gobierno, aún asociado al nombre de un militar, se había formado bajo el signo del poder civil y se buscaba incorporar a aquellos intelectuales de corte europeo, de espíritu liberal, que jamás habían intervenido en política. Era sólo una última y tardía inspiración que el Rey pareció aceptar para salvar la monarquía...

Las últimas páginas de Delirio y destino ofrecen, para nuestro gusto, un menor interés. Las elecciones de abril de 1931; la proclamación de la segunda República en España; los años que presagiaban una contienda civil y fratricida - de la que María Zambrano, tal vez, de propio intento, no escribe ni una sola línea-; el largo y penoso camino hacia el exilio, tal y como ha quedado reflejado en páginas anteriores..., bajan el tono lírico y documental de este libro. El último párrafo quiere cerrar también nuestro comentario: «Insensiblemente se había ido quedando sin sentir, sin sentirse aquí, embebida por una claridad ultraceleste, sin diseño, sin alusión a nada, ni siquiera al horizonte, claridad no coaccionada por la forma del cielo, ni obligada a bajara ninguna tierra, sin peso, número ni medida. Comprendió que era sólo una sombra salida de su pensamiento, que luchaba por despertar, ¿hacia dónde? Y al tener conciencia de ello, despertó enteramente. La tierra estaba allí rojiza y húmeda, color de planeta y de humanidad, 'del primer hombre que se curvó en el trabajo, que se curvó sobre ella ofreciendo su espalda al sol. El barco estaba atracando ya. El muelle estrecho estaba lleno de hombres con el pecho rojizo al aire llevando bultos, trasudando fatiga. Se arregló rápidamente en el cuarto de baño afrontando su cuerpo pálido, de la luz de Europa. Y se encontró al lado de su hermana ${ }^{51}$, bajando la escala, pisando ya la tierra del Nuevo Mundo, en La Guayra. Se dio cuenta de que iba sonriendo, aunque nadie la esperaba; sonreía porque desde lo más adentro de su ser, en ésta, su condición carnal, una voz suya y ajena contestaba a una llamada, a alguien que la había llamado desde muy lejos, insensible, mas imperativamente, y le contestó, desde adentro: «Sí, estoy aquí; sí, estoy aquí... todavía en este mundo» ${ }^{52}$.

\section{Teófilo APARICIO LÓPEZ}

\section{Estudio Agustiniano Valladolid}

50. En enero de 1930 acababa en España la dictadura de don Miguel Primo de Rivera; este gran patriota, que tuvo el vivo anhelo de librar a la nación de la guerra cruenta que presentía. Ni él entendió a los intelectuales de entonces, ni los intelectuales le entendieron a él. Alfonso XIII nombró presidente del Consejo al general Berenguer, al que sin duda se refiere María Zambrano, sin nombrarlo.

51. Se está refiriendo a su fiel y solícita hermana Araceli, que tanta compañía le hizo en el exilio por tierras de América y de Europa.

52. Zambrano, M., Delirio y destino, 1.c., p. 296. 